\section{C.J. Redelinghuys}

Research Fellow, Department of Old and New Testament Studies, University of the Free State, South Africa.

E-mail:

neelsred@gmail.com

DOI: http://dx.doi. org/10.18820/23099089/ actat.Sup26.6

ISSN 1015-8758 (Print) ISSN 2309-9089 (Online)

Acta Theologica 2018

Suppl 26:103-117

(C) Creative Commons With Attribution (CC-BY)
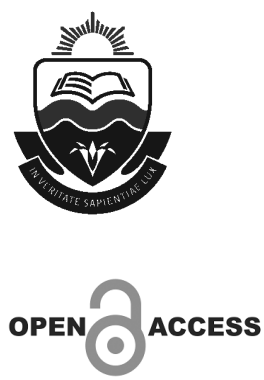

\section{INTERPRETATION,}

ETHICS, AND

THE COMPLEX

RELATIONSHIP

\section{BETWEEN A PROPHET AND AN אָׁשֶׁת זְנוּנִים}

\begin{abstract}
The ontological turn in hermeneutics made it increasingly clear that an interpreter's "inner self" is not detached from the world in which s/he lives. This had a profound impact on not only how one conceives of the process of interpretation, in general, but also how one thinks of ethical evaluation and appropriation, in particular. In this regard, the narrative of Hosea's marriage to Gomer (Hos.1-3) presents an interesting test case for how an interpreter's previously established moral framework influences his/her current understanding of the biblical text. To illuminate this matter, three prominent ethical theories (consequentialism, deontology, and virtue ethics) are used as interpretative frameworks. Finally, the author reiterates that pre-understanding plays an important role in biblical interpretation. This matter is often more complex than simply focussing on theological presuppositions in terms of dealing with different ethical questions and challenges.
\end{abstract}

1 It is my honour to dedicate this article to Prof. Fanie Snyman: an intellectual giant whose love and enthusiasm for the Hebrew Bible also kindled a fire in me; a caring mentor who continuously (and patiently!) guides and motivates me to become a better researcher. Thank you. 


\section{INTRODUCTION ${ }^{2}$}

What is the relationship between an interpreter's "inner self", her/his mind, and the external world? One might feel inclined to say that the mind is isolated and able to evaluate objectively from an "inner island". In the case of written texts such as the Hebrew Bible (HB), this credence would mean that the interpreter, as an outside observer of the text, is free from any kind of prejudice (in a hermeneutical sense). In this regard, Zimmermann (2015:11) explains:

We like to think that no one tells us what to do, and that we make up our own minds after considering all the evidence in a completely unbiased way ... ideas, concepts, and even historical events appear as if passing on a conveyor belt before our mind's eye, from which we take what we consciously decide to make our own.

However, the work of Martin Heidegger (1889-1976) and the so-called "ontological turn" in hermeneutics led to a greater understanding that an interpreter is not a "detached self", looking in from the outside (Zimmermann 2015:34-38). Rather, the interpreter is an active participant in the search for truth and understanding (Westphal 2009:71-72; Zimmermann 2015:12-13). This highlights the "hermeneutical circle": one can only understand a specific subject by making sense of the reciprocal relationship between the whole and its constituent parts (Blackburn 2008:165). While this has proven to be a helpful textual tool in the past, Heidegger and others have shown how this circularity can also apply to life in general (Westphal 2009:35-36; Zimmermann 2015:36-37).

This "existential" domain is worth exploring in more detail in the relationship between biblical interpretation and ethics. According to a linear view of this relationship, there is a natural progression from preunderstanding, to critical testing and explanation (exegesis and theology), to application and/or appropriation. This view has a clearly defined start and end. However, the existential reality is that appropriative understanding in one area again influences one's pre-understanding in another area of inquiry (whether consciously or unconsciously). In practical terms, one can view pre-understanding as a type of database that contains information on a variety of concepts accumulated by different means over an indeterminate period of time (Hill et al. 2011:47-54). Each new attempt at understanding will rely on (or, circle back to) this database, in order to provide a necessary starting-point (Bultmann 1985:72-76).

2 I would like to extend my gratitude to the following persons for their valuable feedback and suggestions that contributed to the final draft of this article: my wife, Rev. Jorina Redelinghuys, and my friend Dr Nic Schmidt (who unfortunately passed away in 2017). 
Take, for example, a group of undergraduate theological students in their first class dealing with the Book of Hosea. If one were to ask them whether Hosea did the "right" thing in marrying Gomer (Hos. 1-3), what would their answers be? Much will depend on what they already know about the narrative, but their answers will also depend on the ethical ideals they established as important some time prior to this particular class. For some, it will be effortless to shift the focus to the larger picture - a view that "the end justifies the means" as it were (consequences). Others will instead focus on the notion of duty: Hosea was "only doing what YHWH called him to do" (perhaps also implying that the prophet had no other choice but to obey). Still others might prefer to highlight the "love" component of the narrative (virtue).

The above answers constitute three distinct articulations of preunderstanding, but which is more accurate?

\section{RESEARCH QUESTION AND METHODOLOGY}

A survey of a number of commentaries shows that the vast majority of scholars are familiar with the ethical questions raised by the HoseaGomer narrative (for example, Simundson 2005:14; McComiskey 2009:11). However, as their focus is mainly on exegetical matters (and a degree of theology), the existential dimension highlighted earlier is understandably not part of their programme. Accordingly, this investigation will utilize a few select ethical theories as interpretative strategies in order to highlight different ways of understanding the prophet's actions and some of the subsequent implications. In this regard, it is important to note that, although this investigation relies on concepts taken from the domain of normative ethics, it merely serves an exploratory function. As such, the aim is not to evaluate the actions of the (biblical) characters as much as it serves to illuminate the interpreter's personal process of understanding.

Bearing in mind these specific aims, the first point of concern is the (exegetical) relationship between Hosea 1 and 3 . This relationship is essential, given that it raises a particular subset of questions that contribute to the overall understanding of the text. Attention then turns to the person of Gomer - her social status and the role she plays within the narrative. The challenge is, among others, to clarify the reference to Gomer as an (Hos. 1:2) and its possible implications. Though the children play a lesser role within the scope of this investigation, one must nevertheless (at least in passing) note how Gomer's status affects the status of the children (Hos. 1:3-9). Finally, because Hosea's marriage arrangement remains problematic from a moral perspective, the investigation will conclude with a reading of the text from the perspective 
of three prominent ethical theories, namely consequentialism, deontology, and virtue ethics.

\section{THE RELATIONSHIP BETWEEN HOSEA 1 AND 3}

At a macro level, the Book of Hosea can be divided into two parts: chapters 1-3 and chapters 4-14, each with its own distinct emphasis and focus (Collins 2004:296; Simundson 2005:3-4; Kwakkel 2012:28-29). Pertinent to this investigation, chapters 1-3 focus on the "material about [Hosea's] personal life, his marriage, and his children" (Simundson 2005:3). While there is hardly any debate over this specific demarcation, the exegete still has to deal with a few other questions. First, chapter 3 seems to mirror chapter 1 in its portrayal of Hosea's marriage, but what is the relationship between these versions? It is plausible to treat these accounts as portraying sequential events in the life of the prophet and his marriage. In this regard, the narrative of chapter 3 merely resumes the relationship started in chapter 1 (Von Rad 1978:112; Garrett 1997:99; Carroll Rodas 2008:241). In turn, Redditt (2008:215) explains the difference in viewpoint between these chapters as a difference in genre: biography (Hos. 1) and autobiography (Hos. 3). As such, Redditt notes, the shift from a thirdperson account to the first-person

results in a greater sense of the prophet's personal pain, in contrast with the more matter-of-fact tone of ch. 1.

Secondly, one has to consider whether Gomer is the unnamed woman in Hosea 3:1. What does the use of ("again") entail? This may relate to YHWH's act of speaking (Garrett 1997:98; Sweeney 2000:38; Simundson 2005:32). One can even apply it to the ensuing imperative ("[again] you must go"; McComiskey 2009:50-51; Nogalski 2011:66). Or, as Collins (2004:299) suggests, it might be an editorial gloss "in view of the fact that the marriage has already been reported once". Whichever of these one prefers, the context seems to demand that Gomer be the woman in question (Garrett 1997:98-99). Consequently, the command to "love" (אטיבה ) her, now called an "adulteress" (from the root נאף), portrays a different perspective on the symbolism that permeates their relationship (Smith 2001:74). In this regard, Yee (1996:231) aptly explains:

Hosea 3:1 plays upon different nuances of the word "love". "Love" characterizes both the profound emotion of Hosea and God and the unfaithfulness of Gomer and the children of Israel ... The love that identifies Hosea's devotion to Gomer and God's passion for the Israelites is a covenantal love. In contrast, the love between the wife and her lover and between Israel and its other gods is an adulterous love (original italics). 
Bearing in mind the relationship between Hosea 1 and 3, the interpreter may then move on to the text's depiction of Gomer and her status in Ancient Israel's society.

\section{GOMER'S STATUS ${ }^{3}$}

The notion that YHWH would command his prophet to marry a woman of Gomer's "social standing" seems a strange one. Numerous commentators throughout history have tried to rationalize or even explain away this issue (Smith 2001:45-46; Heschel 2014:53-54). The command becomes more perplexing if the interpreter takes a general rule of thumb in Ancient Israel to be, as Moon (2015:338) suggests, "that one ought to pursue honor and avoid shame". ${ }^{4}$ However, what exactly the status of Gomer is remains a matter of debate. In this instance, the primary challenge lies in the interpretation of the word זנונוּים (Hos. 1:2), variously represented in contemporary translations as "harlotry" (for example, JPS) or, more degradingly, "whoredom" (for example, NRSV). ${ }^{5}$ Birch (1997:19-20), among others, notes that

an astonishing variety of suggestions have been made about the character of Gomer [including that] [s] he was a prostitute by profession; she was a cult prostitute involved in the fertility rituals associated with Baal; she was a young woman who participated in a Canaanite ritual offering [of] her virginity to Baal; she is simply being described as a woman from a harlotrous people (Israel); she is being described not in terms of what she is but of what she will become as an unfaithful wife.

From the vast amount of literature dealing with the Book of Hosea, three main propositions emerge. First, some commentators maintain that the author's statement cannot be construed as a reference to "prostitution", given the particular word choice and phrasing of the Hebrew text. In this regard, Wolff (1974:13) explains that "riנוּנים "refers to a personal quality, not an activity". Similarly, Stuart (1987:26) notes that the "plural abstract refers more to a trait than a profession". According to this view, the author would

3 As an aside, the interpreter should bear in mind that the text provides the reader with an obviously one-sided characterization of Gomer as a woman and omits the (possible) reasons and explanations for her life choices. See Sweeney (2000:15-16).

4 In other words, the shame that attaches to the household through illicit sexual behaviour.

5 The interpreter should be wary of how s/he appropriates these terms in the contemporary context, given the violent and abusive overtones. See Yee (1996:206-209); Kelle (2013:122). 


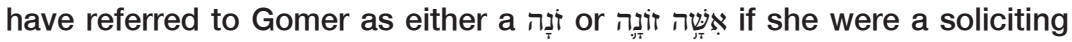
prostitute (Josh. 2:1). Consequently, the reference to Gomer as "harlotrous" is seen to be, at least to some extent, a general one, given the socioreligious context in which the text is set (Green 2003:85). In other words, Gomer is merely a regular person through whom the prophetic symbolism ultimately comes to fruition. Stuart (1987:26-27) explains this as follows:

\begin{abstract}
Gomer, as a citizen of that thoroughly wayward nation is described, just as any Israelite woman could be, as an אשת זנונים precisely because she is a typical Israelite, and this is an indictment in itself. God has commanded Hosea to marry a woman who by reason of being involved in the endemic Israelite national unfaithfulness is "prostituting". To marry any Israelite woman was to marry a "prostituting woman", so rife was the religious promiscuity of Hosea's day (original italics).
\end{abstract}

Secondly, other commentators assert that Gomer was a promiscuous woman - not a prostitute, but probably more than simply "a typical Israelite" (Yee 1996:216; Ben Zvi 2004:379; McComiskey 2009:14). In this

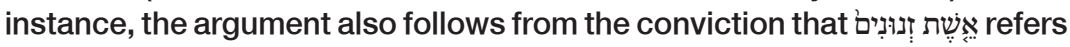
to a specific trait and/or behaviour, but not her profession (Garrett 1997:51; Carroll Rodas 2008:228). This means that

she interacts sexually with male partners with whom she is not supposed to, according to the accepted social and ideological norms [of that time] (Ben Zvi 2004:379).

Moreover, "[her] sexual acts are evaluated pejoratively" as being like (or similar to) those of a harlot (Yee 1996:216). The assertion is that Gomer was already promiscuous prior to the marriage, and Hosea was well aware of this behaviour in taking her as his wife (Ben Zvi 2004:379-380; Collins 2004:297). The implication is also that her behaviour did not change after her marriage (Birch 1997:20).

Finally, some commentators maintain that Gomer was a kind of prostitute when Hosea married her (Hays 2010:268). In the patriarchal context of Ancient Israel, "prostitution" was not necessarily a case of immorality, but sometimes economic necessity - a way in which a woman could support herself financially if there was no other way (Sweeney 2000:15; Dempsey 2013:43). If this is also the case for Gomer, then any theological scrutiny of her character might be rash. It is possible, however, that Gomer was a cult prostitute; this would make for a stronger connection between the embodying concepts of idolatry and adultery (Simundson 2005:15-16; Redditt 2008:219). 
To make sense of this designation, one can turn to the narrative of Genesis 38 for comparison. In verse 15, Judah thought that Tamar was a ți, a prostitute, when he chose to have sexual intercourse with her. In Genesis

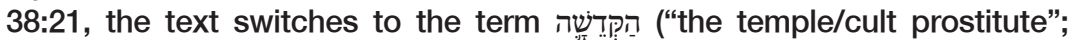
Gen. 38:22; Hos. 4:14). However, in verse 24, the people refer to Tamar's

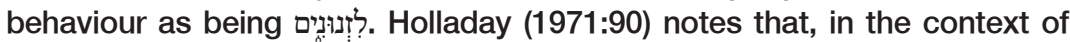
Genesis 38, the use of the term may refer to the "circumstance and practice of the zonnâ", while it may apply to "a woman endowed with the tendency to prostitute" in Hosea. The LXX manages to capture the same sense of ambiguity through its use of the term ropveía in Hosea 1:2. The word generically refers to various kinds of sexual sin, including "fornication, sexual immorality, prostitution" (Friberg et al. 2000 italics original).

Bearing in mind the above discussion, it seems plausible to view Gomer as either a promiscuous woman or a prostitute (whether common or cultic). Given the implication that Gomer will not change her ways after her marriage, both views also fit the description of "adultery" in Hosea 3. Therefore, both of these views will be incorporated into the process of ethical reflection. In this instance, one can also include a short note on the children: in the case of both readings, the reference to the children will be as such purely because of their mother's status (Simundson 2005:16; Dempsey 2013:43; Moon 2015:344). In other words, whether Gomer is a prostitute or a promiscuous woman, the description of the children will follow suit.

\section{THE ETHICAL DIMENSION(S) OF HOSEA'S MARRIAGE TO GOMER}

Given the discussion thus far, the question remains as to whether one can construe Hosea's actions as "ethical". In other words, did he do the right thing in marrying Gomer? The answer to this question is not as straightforward as the question itself, as some contemporary JudeoChristian readers would seem to suggest. On the one hand, it remains important not to detach the marriage from its historical, sociocultural, and religious context. On the other hand, it soon becomes clear that the interpreter's personal moral framework has an influence on how s/ he perceives Hosea's actions in the said context. For the purposes of this investigation, the assumption is that an interpreter will subscribe (consciously or unconsciously) to one of the following ethical theories, or at least certain elements thereof: consequentialism (utilitarianism), deontology, or virtue ethics. ${ }^{6}$

6 For an introductory discussion of each theory as well as some pros and cons, see Warburton (2013:39-55). 


\subsection{Consequentialism}

Consequentialism refers to ethical theories that emphasize outcomes or consequences as a guide for ethical decision-making (Blackburn 2008:74-75). For the purposes of this investigation, the focus will be on the best known version of consequentialism, namely "utilitarianism". Following Jeremy Bentham (1748-1832) and John Stuart Mill (1806-1873), utilitarians emphasize choices and/or actions that either maximize happiness or minimize suffering (Warburton 2013:47). In this regard, Warburton (2013:47) explains that

the right action in any circumstances can be calculated by examining the probable consequences of the various possible courses of action.

The key phrase, in this instance, is "probable consequences", because, as Warburton further points out, it is inconceivable to think that any given person can, in all circumstances, know or accurately predict what the outcome of his/her actions will be. At the very least, then, one should strive to attain the greatest balance of happiness over unhappiness for the greatest number of people.

In the case of Hosea, the interpreter can tangibly ground the "probable consequences" of his actions in the covenant (see Barton 2002:82-84). The prophet proceeds from the perspective that, if the people continue in their sinful ways, punishment will surely follow. The various curses set out in Leviticus 26 and Deuteronomy 28 provide some insight into what such a future might be. Ultimately, this option holds no "happiness" for either YHWH or his people. Conversely, however, if the people repent and repair their relationship with $\mathrm{YHWH}$, the covenantal blessings will follow. Given the necessary actions he will have to take, this option may be an uncomfortable one for Hosea (and perhaps even for Gomer), but this is the option that holds the best probable outcome for the greatest number of people. Ultimately, his own happiness and reputation become secondary matters; all that is important now is Israel's future and their continuing relationship with their God.

Finally, whether Gomer is a promiscuous woman, or a prostitute has hardly any effect on a utilitarian's reading of the text. Throughout, the focus remains on the consequences of Hosea's actions and not the deed in itself. To that end, the repaired relationship between $\mathrm{YHWH}$ and his people is the only point of concern. In this sense, a utilitarian interpretation is relatively straightforward. However, two secondary questions remain. Does it matter that the interpreter knows of the actual outcome of events (in other words, 
destruction of Samaria and exile)? Would it make a difference if Hosea knew from the onset that the outcome will be a bad one?

\subsection{Deontology}

Whereas proponents of consequentialism primarily focus on the consequences of an action or decision, the act itself comes into view in deontological ethics. In particular, it places an emphasis on duties, rights, and/or the right type of actions in a given situation (Blackburn 2008:94). Following Immanuel Kant (1724-1804), and emphasizing the role of reason in decision-making, two forms of the so-called "categorical imperative" prove relevant for this reading of Hosea. The first form concerns the "universal law". This is the notion, as Warburton (2013:43) summarizes, that one ought to act only on those principles "you would rationally want to apply to everybody". The second form deals with the notion that one ought not to use people as means to an end. Warburton (2013:44) explains that the focus, in this instance, is on respect for, and recognition of a person's humanity: "the fact that they are individuals with wills and desires of their own".

Considering Hosea's actions from a deontological perspective proves to be a challenging and multifaceted matter that uncovers a certain amount of tension (on both a textual and personal level). One might consider these tensions by noting whether Hosea did the "right" thing and then highlighting certain counterpoints, where applicable.

First, Hosea did the right thing, as it is his duty as a prophet always to obey the commands of YHWH; perhaps even wills all of Israel to obey the commands of God in all circumstances. This proves to be the basic principle that undergirds the covenant (Lev. 20:8). However, would one wish for the people to engage in morally eccentric behaviour on a universal scale as long as they sincerely conceive of it to be a command from YHWH? It is true that the biblical narrative often paints a picture in which the prophets have to go to extreme (or unusual) lengths to convey YHWH's message (for example, Isa. 20:1-6). However, the main concern, in this instance, is ethical consistency: rules apply to society as a whole and not merely to the prophets and/or priests. In this regard, the apparent "strangeness" of an action hardly presents a cogent argument for behaviour one should imitate.

Secondly, contrary to the priests (Lev. 21:7, 14), there seems to be no religious law that prohibits Hosea from marrying a common prostitute (Barton 2002:48-49). On this point, Hosea seems to have acted correctly. For comparison, one may consider select laws that deal with adultery and temple prostitution, in general, and pose a few questions. Was Gomer 
married to another man at the time that she and Hosea started their relationship? (Lev. 18:20; 20:10; Deut. 22:22). Did Hosea divorce Gomer? Did she take another husband before Hosea took her back at a later stage? (Deut. 24:1-4). Deuteronomy 23:18 [MT] seems to outlaw the practice of temple prostitution, but what are the implications of entering a relationship with a person who carries this status? As the text provides insufficient details about the lives of either Hosea or Gomer, one can only speculate about the possible answers to any of these questions.

Finally, even if one grants that Hosea's actions are not wrong per biblical and/or ancient societal laws, there may still be a sense of unease over the prophet's treatment of Gomer as a person. Leviticus 19:18 teaches the people "to love your neighbour as yourself" (NRSV). Other texts caution the people against the mistreatment of specific groups of people, for example widows and orphans (Ex. 22:21-22 [MT]). Yet, unlike the articulation of the "golden rule" in the Christian New Testament (Matt. 7:12a), the HB provides no direct equivalent. Still, it is of interest to note that Jesus Christ interprets this maxim as the foundation of "the law and the prophets" (Matt. 7:12b). Considering the various texts, one can construct an argument for treating people with respect, although this does not necessarily rule out using them as a means to an end.

\subsection{Virtue ethics}

Finally, attention turns to Hosea's moral character, which provides the subject matter of an evaluation from the perspective of virtue ethics (see Carroll Rodas 2001:82). Generally, following the ancient Greek philosopher Aristotle (384-322 BCE), "virtue theorists focus on character and are interested in the individual's life as a whole" (Warburton 2013:53). To live a "good" life, one has to cultivate certain virtues and, in doing so, one can achieve eudaimonia ("flourishing") (Warburton 2013:53). What is a "virtue"? Warburton (2013:53) explains that a "virtue" is "a pattern of behaviour and feeling: a tendency to act, desire, and feel in particular ways in appropriate situations". Of course, the cultivation of these virtues does not happen in isolation. As Carroll Rodas (2001:84) points out, a given

community establishes for itself what the "good" is for its members and tries to mold them in accordance with it.

In the context of Hosea, much like in the other prophetic books (see Carroll Rodas 2001:86-87), living a good life is set within the confines of YHWH's covenant with his people. In this regard, "fidelity" and "obedience" prove to be important virtues - the good life is a life that is faithful to YHWH and obedient to the covenant stipulations. One could perhaps also argue 
that "love" is an important virtue, although this finds tangible expression in and through fidelity and obedience. Much of this reading seemingly overlaps with the utilitarian's perspective. The difference, however, lies in the motivation for living a life of fidelity and obedience. While the consequences of his actions might be beneficial (§5.1), the virtue theorist maintains that these virtues are good in and of themselves regardless of what the outcome might be. Was Hosea a man of good moral character? The text would seem to allow for a positive response to this question.

\section{CONCLUDING REMARKS}

Hosea's marriage to Gomer presents an interesting test case for how an interpreter's moral framework affects his/her understanding of the biblical text. With this in mind, it was the purpose of this investigation to determine whether Hosea's actions were "morally correct" in light of three prominent ethical theories: consequentialism (utilitarianism), deontology, and virtue ethics.

- The utilitarian interpreter emphasizes the probable consequences of Hosea's actions. In this regard, when considering the covenant between YHWH and Israel, the blessings when they are obedient and the curses that follow disobedience, it would seem that Hosea acted morally correct.

- The deontologist focuses on such aspects as duty, rights, and the right type of actions. In this instance, the interpreter might encounter some measure of tension. On the one hand, it was Hosea's duty to obey YHWH, but the peculiar deed raises some questions. On the other hand, Hosea did not seem to break any ancient societal or religious laws; yet his treatment of Gomer might cause some unease with the contemporary interpreter.

- The virtue theorist focuses on the virtues that would have been important to Hosea and the Ancient Israelite community. In this regard, considering the role of the covenant, fidelity and obedience emerge as viable options.

Three different articulations of pre-understanding have now given way to three distinct, though not completely unrelated interpretations of the Hosea text. Again, the question(s): Which one of these interpretations is more accurate? Or is there an element of truth to all of them?

As mentioned earlier, one can conceive of "pre-understanding" in terms of an information database. This database contains all of the interpreter's thoughts, feelings, beliefs, and so on as it relates to different 
phenomena (Hill et al. 2011:47-54). The database might start small at first, with information on a limited number of concepts, but the interpreter will constantly incorporate more concepts as s/he encounters more occasions that necessitate "understanding". In the case of the undergraduate students mentioned earlier, this may be their first encounter with Hosea, but they will already have some information on concepts such as "morality", "prophets", and even "prostitution/promiscuity". Moreover, they will be able to connect these concepts to one another. The simple equation "morality + prostitution", for example, might lead to a statement such as "prostitution is wrong". This conceptual foundation or established "life relation", as Bultmann (1985:75) refers to it, provides them with an entry point into the text.

In a sense, it might seem arbitrary to highlight these different moral categories in a discussion about pre-understanding in biblical interpretation. Ultimately, the majority of (if not all) hermeneutic thinkers agree that interpretation without presupposition is not possible (Zimmermann 2015:37-38). However, it is an underappreciated fact that, even if one is or becomes aware of these presuppositions, it is no guarantee that the hermeneutical process will serve as a corrective. Westphal (2009:72), for example, frames this matter as follows:

We can never become fully conscious of our prejudices because every effort at such self-examination will itself be guided by presuppositions not yet brought to reflective transparency, and even when we become aware of aspects of our formation, these elements do not stop working but continue to do so, often behind our backs.

The aim, in this instance, is not to descend into some form of relativism, but to emphasize three important points. First, it is a general reminder that the relationship between pre-understanding, interpretation, and application/appropriation is not a linear one. Secondly, given the cyclical nature of this process, it specifically reminds the interpreter to consider his/her specific presuppositions critically and carefully with each new attempt at understanding. Thirdly, it is an appeal to consider cognitive science research on such topics as belief-formation and the spectrum of cognitive biases, especially paying attention to how these matters influence decision-making (Alcock 1995; McAuliffe 2016).

In conclusion, the Hosea example might invite strong opinions from exegetes and theologians alike, but ultimately it is a (seemingly) harmless way to illuminate the relationship between morality and pre-understanding. However, this is not true for all biblical texts that require ethical analyses. In other words, while discussions such as these are generally theoretical 
in nature, it is worth remembering that application/appropriation often has real-life consequences (see Spong 2005). This makes it a matter worth fretting over continuously.

\section{BIBLIOGRAPHY}

ALcock, J.E. 1995. The belief engine. [Online.] Retrieved from: https://www.csicop.org/SI/ show/belief_engine/default.asp [2018, 30 June].

BARTON, J. 2002. Ethics and the Old Testament. Second edition. London: SCM Press.

Ben Zvi, E. 2004. Observations on the marital metaphor of YHWH and Israel in its Ancient Israelite context: General considerations and particular images in Hosea 1:2. Journal for the Study of the Old Testament 28(3):363-384.

BIRCH, B.C. 1997. Hosea, Joel, and Amos. Louisville, KY: Westminster John Knox. Westminster Bible Commentary.

BLACKBURN, S. 2008. Oxford dictionary of philosophy. Second edition revised. Oxford: Oxford University Press.

Bultmann, R.

1985. New Testament and mythology: And other basic writings. S.M. Ogden (ed.) London: SCM Press.

Carroll Rodas, M.D.

2001. Seeking the virtues among the prophets: The Book of Amos as a test case. Ex Auditu 17:77-96.

2008. Hosea. In: T. Longman III \& D.E. Garland (eds), Daniel-Malachi. Revised edition (Grand Rapids, MI: Zondervan, EBC 8), pp. 213-305.

Coluins, J.J. 2004. Introduction to the Hebrew Bible. Minneapolis, MN: Fortress Press.

DEMPSEY, C.J. 2013. Amos, Hosea, Micah, Nahum, Zephaniah, Habakkuk. Collegeville, MN: Liturgical Press. NCBS 15.

Friberg, T., Friberg, B. \& Miller, N.F. 2000. Analytical lexicon of the Greek New Testament. Electronic edition. Grand Rapids, MI: Baker Books. BibleWorks, 8.

Garrett, D.A. 1997. Hosea, Joel. Nashville, TN: B\&H Publishing Group. NAC 19A. 
Green, Y.

2003. Hosea and Gomer revisited. Jewish Bible Quarterly 31(2):84-89.

HAYS, J.D.

2010. The message of the Prophets: $A$ survey of the prophetic and apocalyptic books of the Old Testament. Tremper Longman III (ed.). Grand Rapids, MI: Zondervan.

Heschel, A.J. 2014. The Prophets. Single volume edition. Peabody, MA: Hendrickson Publishers.

Hill, H., Gutt, E.A., Hill, M., Unger, C. \& Floyd, R. 2011. Bible translation basics: Communicating scripture in a relevant way. Dallas, TX: SIL International.

HolLadAY, W.L. 1971. A concise Hebrew and Aramaic lexicon of the Old Testament. Leiden: Brill.

KeLLE, B.E. 2013. Hosea. In: J.B. Green \& J.E. Lapsley (eds), The Old Testament and ethics: A book-by-book survey (Grand Rapids, Ml: Baker Academic), pp. 121-123.

KWAKKEL, G. 2012. Hosea, prophet of God's love. In: H.G.L. Peels \& S.D. Snyman (eds), The lion has roared: Theological themes in the prophetic literature of the Old Testament (Eugene, OR: Pickwick Publications), pp. 27-39.

McAuliffe, K.

2016. How disgust made humans cooperate to build civilisations. [Online.] Retrieved from: https://aeon.co/essays/how-disgust-made-humans-cooperateto-build-civilisations [2016, 26 July].

McComiskeY, T.E.

2009. Hosea. In: T.E. McComiskey (ed.), The minor prophets: An exegetical and expository commentary. Single volume edition. (Grand Rapids, MI: Baker Academic), pp. 1-237.

Moon, J.

2015. Honor and shame in Hosea's marriages. Journal for the Study of the Old Testament 39(3):335-351.

NogaLSKI, J.D.

2011. The Book of the Twelve: Hosea-Jonah. Macon, GA: Smyth \& Helwys Publishing Incorporated.

RedDITT, P.L.

2008. Introduction to the Prophets. Grand Rapids, MI: W.B. Eerdmans. 
SiMUNDSON, D.

2005. Hosea, Joel, Amos, Obadiah, Jonah, Micah. Nashville, TN: Abingdon Press. AOTC.

SMITH, G.V. 2001. Hosea, Amos, Micah. Grand Rapids, MI: Zondervan. NIVAC.

SPONG, J.S. 2005. The sins of scripture: Exposing the Bible's texts of hate to reveal the God of love. New York: HarperOne.

StUART, D.

1987. Hosea-Jonah. Nashville, TN: Thomas Nelson, Inc. WBC 31.

SWEENEY, M.A.

2000. The Twelve Prophets, Volume 1. Collegeville, PA: The Liturgical Press. Berit Olam.

Von RAD, G.

1978. The message of the prophets. Sixth impression. London: SCM Press.

Warburton, $\mathrm{N}$.

2013. Philosophy: The basics. Fifth edition. London: Routledge.

WestPhaL, M.

2009. Whose community? Which interpretation? Philosophical hermeneutics for the church. Grand Rapids, Ml: Baker Academic.

WolfF, H.W.

1974. Hosea. Translated by G. Stansell. Philadelphia, PA: Fortress Press. Hermeneia.

YEE, G.A.

1996. The Book of Hosea. In: L.E. Keck (convenor), Introduction to the apocalyptic literature, Daniel, the twelve prophets (Nashville, TN: Abingdon Press, NIB 7), pp. 195-297.

ZIMMERMANN, J.

2015. Hermeneutics: A very short introduction. Oxford: Oxford University Press.

Keywords

Hebrew Bible

Hosea 1-3

Hosea and Gomer

Biblical interpretation

Ethics
Trefwoorde

Hebreeuse Bybel

Hosea 1-3

Hosea en Gomer

Bybelinterpretasie

Etiek 